BIOMEDICAL AND BIOSOCIAL ANTHROPOLOGY
$\begin{gathered}\text { Official Journal of the International Academy } \\ \text { of Integrative Anthropology } \\ \text { journal homepage: http://bba-journal.com }\end{gathered}$

\title{
Peculiarities of organometric parameters of the hard palate in the second and third trimester of the intrauterine development and newborns
}

Prodanchuk A. I., Slobodian O. M., Korchynska N. S.

Higher State Educational Establishment of Ukraine "Bukovinian State Medical University", Chernivtsi, Ukraine

\section{ARTICLE INFO}

Received: 5 September, 2018

Accepted: 30 October, 2018

UDC: $611.315 .013 .068-053.15 / .31$

\section{CORRESPONDING AUTHOR}

e-mail: prodanchukanna@gmail.com Prodanchuk A. I.
Finding anatomical variability of organs, structures and their parts at all the stages of human development is rather topical. Determination of organometric parameters of the hard palate in fetuses and newborns is an essential part for perinatal diagnostics and understanding real parameters of the norm and pathology. Purpose of the study is to find organometric parameters of the palatine maxillary process and horizontal lamina of the palatine bone during fetal and early neonatal periods of human ontogenesis. By means of adequate anatomical methods of examination the study was conducted on 53 specimens of dead fetuses from 4 to 10 months of fetal development (from $165.0 \mathrm{~mm}$ to $500.0 \mathrm{~mm}$ of the parietal-calcaneal length (PCL)) and 9 specimens of dead neonates. The length of the palatine maxillary process during the perinatal period was found to be characterized by the two periods of accelerated development (5-7 and 8-10 months), and the period of relatively slow development (7-8 months). Its width was found to be characterized by the two period of accelerated development (5-7 and 9-10 months), and relatively slow development (7-8 months). The length of the horizontal lamina of the palatine bone is characterized by the period of accelerated development from 8 to 10 months, and the period of relatively slow development from 7 to 8 months. Meanwhile 58 and 9-10 months were the periods of accelerated development for its width, and 8-9 months - the period of relatively slow development for it. During fetal and early neonatal periods of human ontogenesis the value of all the paired correlation coefficients between organometric parameters of the palatine maxillary process (hard palate) and horizontal lamina of the palatine bone are positive and rather close to $1(>0.84)$, which is indicative of a close positive correlation between all the organometric parameters. Very strong relation is found between the length of the hard palate and its width in the right and left ( $r=0.92)$, between the length of the hard palate and palatine bone ( $r=0.97)$, between the length of the palatine bone and the width of the hard palate in the right $(r=0.91)$ and in the left ( $r=0.90)$. Therefore, by means of adequate anatomical methods of examination new scientifically substantiated data are obtained concerning organometric characteristics of anatomical structures of the hard palate at all the stages of perinatal period.

Keywords: palatine maxillary process, horizontal lamina of the palatine bone, morphometry, fetal and early neonatal period of human ontogenesis.

\section{Introduction}

Finding anatomical variability of organs, structures and their parts at all the stages of human development is rather topical [2]. Defects of the dentoalveolar system rank one of the main places among pathology of the maxillary-facial region, and according to the data of certain authors their occurrence is from 70 to $80 \%[1,3,4,16]$. One of the common congenital developmental defects of the maxillaryfacial region is cleft of the lip and hard palate named "harelip" and "cleft palate". Severity of congenital facial defects is manifested not only by external deformation and functional impairments but negative effect on the child's psychic development as well $[5,8,15]$.

The conducted investigation substantially supplies existing data concerning establishment of the structure and topography of the hard palate during the fetal and early neonatal periods of human ontogenesis, which is an 
essential constituent while making perinatal diagnostics and understanding of real data of the norm and pathology $[6,7,9,20]$. The obtained scientifically substantiated data concerning organometric characteristics of anatomical structures of the hard palate during all the stages of perinatal period determine the morphological basis and are important for finding the criteria of the hard palate morphogenesis and its correspondence with the terms of pregnancy $[10,17]$.

Nowadays organometric parameters of the hard palate in fetuses and newborns followed by the determination of its forms and types are not sufficiently studied [13].

Purpose of the study is to find organometric parameters of the palatine maxillary process and horizontal lamina of the palatine bone during fetal and early neonatal periods of human ontogenesis.

\section{Materials and methods}

The study was conducted on 53 specimens of dead fetuses from 4 to 10 months of fetal development (from 165.0 $\mathrm{mm}$ to $500.0 \mathrm{~mm}$ of the parietal-calcaneal length (PCL)) and 9 specimens of dead neonates of both sexes died of the causes not associated with diseases of the digestive tract, without external signs of anatomical defects, and without visible macroscopic departure from the normal cranial structure. Adequate anatomical methods were applied during investigation: macropreparation, making topographic-anatomical sections, morphometry, and statistical analysis. The study is conducted according to the main requirements of the Helsinki Declaration of the World Medical Association as a statement of ethical principles for medical research involving human subjects (1964-2000) and the Order of the Ministry of Health of Ukraine № 690, dated 23.09.2009. It is a fragment of a comprehensive planned initiation scientific-research work of M.H. Turkevych Department of Human Anatomy, and Department of Anatomy, Topographic Anatomy and Operative Surgery, the Higher State Educational Establishment of Ukraine "Bukovinian State Medical University": "Peculiarities of morphogenesis and topography if the organs and systems during prenatal and postnatal periods of ontogenesis " (state registration № 0115U002769).

Both fresh and fixed dead bodies of fetuses and newborns were used for macropreparation. PCL of the fetus was measured before the beginning of the study. Anatomical peculiarities of the processes of the upper jaws and horizontal laminas of the hyoid were investigated after these structures were prepared. After that by means of a tape measure, sliding compasses and dial caliper, the main parameters of the hard palate were measured including: the length of the palatine maxillary process, the width of the palatine maxillary process in the left and right (the most distant points between the middle palatine suture and middle edge of the dental cells), length and width (in the left and right) of the horizontal lamina of the palatine bone.

The obtained findings were statistically processed by means of the licensed program RStudio. The null hypothesis was checked concerning the fact that the samples were taken from one distribution, or from distributions with similar medians:

$\mathrm{H}_{0}$ : every group has similar distribution\}

$\mathrm{H}_{1}$ : \{every group does not have similar distribution\}

Student test, non-parametric Kruskal-Wallis test (answers the question if there is any difference between group distributions, but does not indicate what groups differ), Connowre-Iman test to compare stochastic domination and obtain the results between different paired comparison after Kruskal-Wallis test for stochastic domination among $\mathrm{k}$ groups were applied in the study. While making the analysis of selective correlation coefficient $(r)$ the connection strength was assessed according to Cheddok scale: with $r=0$ - no connection; with $r=$ from 0.1 to 0.3 - mild connection; 0.3-0.5 - moderate connection; 0.5-0.7 - visible connection; 0.7-0.9 - high power connection, 0.9-1 - very high power connection. Statistically valuable were values with $p<0.05$.

\section{Results}

During the second trimester of the intrauterine development the length of the palatine maxillary process increases from $6.761 \pm 0.172 \mathrm{~mm}$ to $13.73 \pm 0.81 \mathrm{~mm}$, the width from the left - from $3.414 \pm 0.113 \mathrm{~mm}$ to $7.321 \pm 0.253$ $\mathrm{mm}$, the width from the right - from $3.613 \pm 0.121 \mathrm{~mm}$ to $7.671 \pm 0.233 \mathrm{~mm}$, the length of the horizontal lamina of the palatine bone - from $2.834 \pm 0.081 \mathrm{~mm}$ to $4.532 \pm 0.133 \mathrm{~mm}$, the width - from $5.972 \pm 0.111 \mathrm{~mm}$ to $11.59 \pm 0.34 \mathrm{~mm}$. During the third trimester of the intrauterine development and newborns these organometric parameters increase in the following way: the length of the palatine maxillary process increases from $11.86 \pm 0.27 \mathrm{~mm}$ to $24.71 \pm 0.33 \mathrm{~mm}$, its width in the left - from $8.083 \pm 0.311 \mathrm{~mm}$ to $10.41 \pm 0.16 \mathrm{~mm}$, in the right - from $8.181 \pm 0.361 \mathrm{~mm}$ to $10.72 \pm 0.16 \mathrm{~mm}$, the length of the horizontal lamina of the palatine bone - from $4.621 \pm 0.111 \mathrm{~mm}$ to $8.684 \pm 0.111 \mathrm{~mm}$, the width - from $14.42 \pm 0.95 \mathrm{~mm}$ to $16.04 \pm 0.19 \mathrm{~mm}$ (Fig. 1-5).

The correlation between all the organometric parameters of the palatine maxillary process (hard palate)

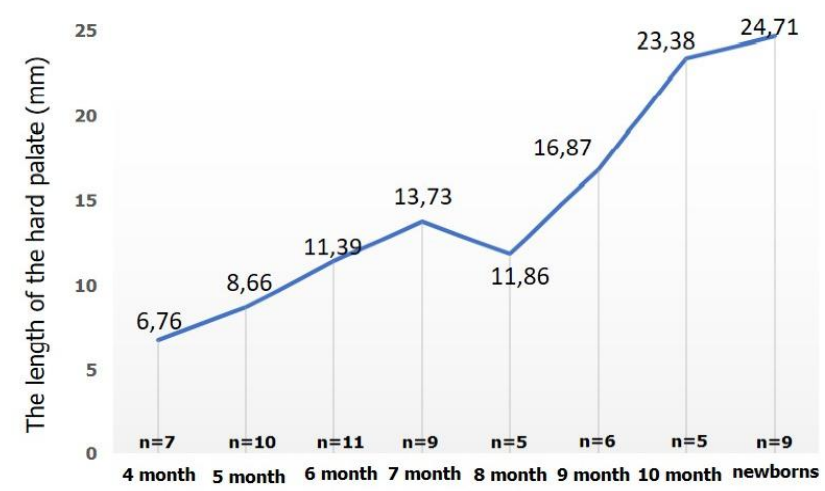

Fig. 1. Diagram of mean values of the length of the palatine maxillary process (hard palate) during the second and third trimesters of the intrauterine development. 


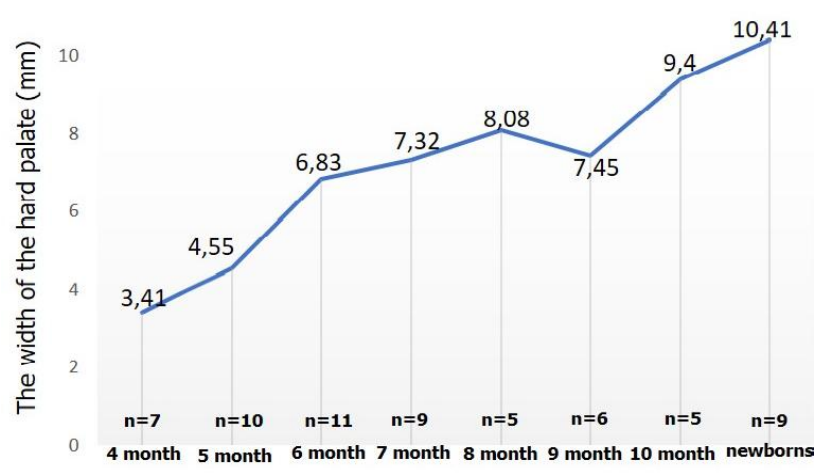

Fig. 2. Diagram of mean values of the length of the palatine maxillary process (hard palate) in the left during the second and third trimesters of the intrauterine development.

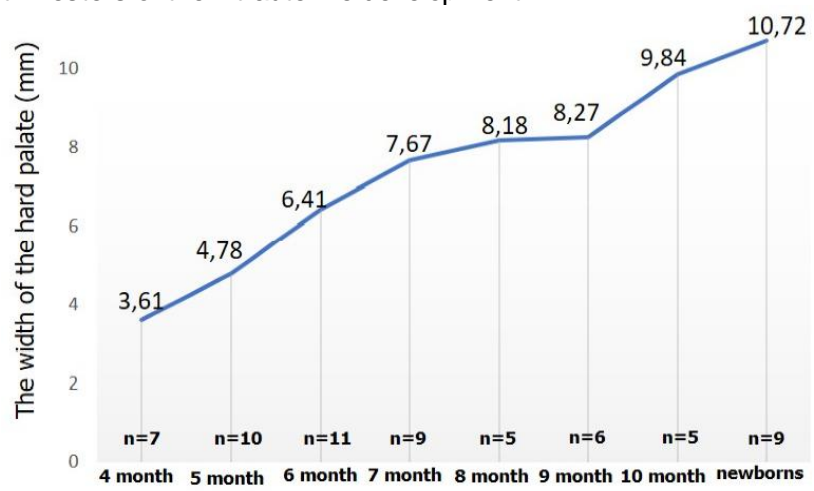

Fig. 3. Diagram of mean values of the length of the palatine maxillary process (hard palate) in the right during the second and third trimesters of the intrauterine development.

and horizontal lamina of the palatine bone during the perinatal period determined that the values of all the paired correlation coefficients are positive and rather close to 1 $(>0.84)$, which is indicative of a close positive correlation between all the organometric parameters.

\section{Discussion}

In the result of organometric measurements of the palatine maxillary process (hard palate) and horizontal lamina of the palatine bone during fetal and early neonatal periods of human ontogenesis it can be suggested that these structures are characterized by the periods of accelerated and relatively slow development. Certain data concerning organometric parameters of the hard palate are presented in the works by Guzik N. M. [11], Sane V. D. et al. [14], Tessler A. Y. et al. [19]. The length of the palatine maxillary process during the perinatal period was found to be characterized by the two periods of accelerated development (5-7 and 8-10 months), and the period of relatively slow development (7-8 months). Its width was found to be characterized by the two period of accelerated development (5-7 and 9-10 months), and relatively slow development (7-8 months). The length of the horizontal lamina of the hyoid is characterized by the period of accelerated development from 8 to 10 months, and the period of relatively slow development from 7 to 8 months.

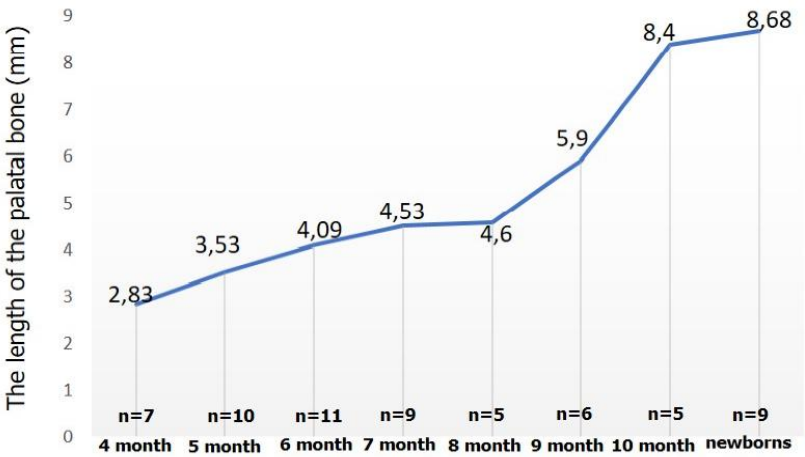

Fig. 4. Diagram of mean values of the horizontal lamina length of the palatine bone during the second and third trimesters of the intrauterine development.

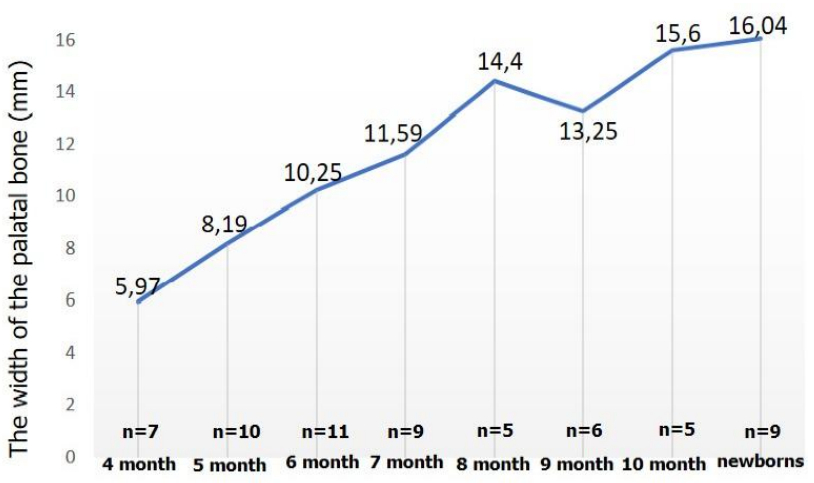

Fig. 5. Diagram of mean values of the horizontal lamina width of the palatine bone during the second and third trimesters of the intrauterine development.

Meanwhile 5-8 and 9-10 months were the periods of accelerated development for its width, and 8-9 months the period of relatively slow development for it.

Thus, for all the possible parameters of the hard palate in the second and third trimesters of the intrauterine development the periods of accelerated development were found in the middle and end of the fetal period of human ontogenesis. Practically in all the cases 7-8 months is the period of relatively slow development for these parameters.

In our opinion, a close positive correlation between all the organometric parameters of the palatine maxillary process (hard palate) and horizontal lamina of the palatine bone during the perinatal period is indicative of a considerable degree of integration and substantial synergism of accelerated and relatively slow periods of development of the examined structures $[12,18]$.

On the basis of the obtained parameters it was found that for the length of the palatine maxillary process (hard palate) during perinatal period the difference between medians of sampling is statistically significant $(p<0.001)$. Connowre-Iman test resulted in finding the fact that the median difference in all the possible pairs of age groups for the length of the hard palate is statistically significant, except the pairs "6 months - 8 months", "7 months - 8 months", "7 months - 9 months", "10 months - newborns", that enables to suggest that intensive growth of the hard palate is from 
the $4^{\text {th }}$ to $7^{\text {th }}$ month. Later the parameter of the hard palate becomes statistically significant in 8-month fetuses compared with the 9-month ones $(p<0.01)$ and 9-month fetuses in comparison with 10 -month fetuses $(p<0.01)$.

Conducted Kruskal-Wallis test gave the following results for the width of the palatine maxillary process (hard palate): since $p<0.05$, the difference between group medians is statistically significant. Connowre-Iman test determined that median difference for all the possible pairs of age groups is statistically significant, except the pairs "7 months - 8 months", "7 months - 9 months", "8 months - 9 months", "10 months - newborns". On the basis of the obtained data it can be suggested that the periods of the most intensive growth of the hard palate width occurs from the $4^{\text {th }}$ to the $7^{\text {th }}$ month, and the period of relatively slow development - from the $7^{\text {th }}$ to the $9^{\text {th }}$ month. Considerable differences between the mean values of the hard palate width in the left and right were not found among any age groups $(p>0.05)$. Similar conclusions are obtained for the medians (hard palate width) by age groups ( $p>0.05$ ).

The difference between the medians of sampling the length of the palatine bone by the age groups is statistically significant $(p<0.001)$. The median difference for all the possible pairs of age groups is statistically significant except the pairs "7 months - 8 months", "8 months - 9 months", "10 months - newborns". The larger parameter of the palatine bone length I $\mathrm{n}$ the 9-month fetuses compared with the 10-month fetuses is statistically significant $(p<0.01)$.

Under conditions of the analysis of the palatine bone width according to age groups the difference between medians of sampling is statistically significant $(p<0.001)$, except the pairs "8 months -10 months", "7 months - 9 months", "8 months - 9 months", "8 months - newborns", "10 months - newborns". The parameter of the palatine bone width increases to the $8^{\text {th }}$ month. Considerable difference between the mean values of the palatine bone width from the $8^{\text {th }}$ to the $9^{\text {th }}$ month was not found $(p=0,059)$, statistically significant is the parameter of the 9-month

\section{References}

[1] Akarsu-Guven, B., Karakaya, J., Ozgur, F., \& Aksu, M. (2015). Growth-related changes of skeletal and upper-airway features in bilateral cleft lip and palate patients. Am. J. Orthod. Dentofacial Orthop., 148(10), 576-586. doi: 10.1016/ j.ajodo.2015.02.031

[2] Akhtemiychuk, Yu. T., Slobodyan, O. M., Hmara, T. V., Zavolovych, A. I., Oliynyk, I. Yu., Pronyayev, D. V., ... Kryveckiy, V. V. (Ed. Yu. T. Ahtemiychuk) (2011). Essays on perinatal anatomy. Chernivtsi: BSMU.

[3] Bernadskiy, Yu. I. (2006). Traumatology and reconstructive surgery of the cranio-maxillofacial area (3rd ed.). Moscow: Medicine.

[4] Celikoglu, M., Buyuk, S. K., Sekerci, A. E., Cantekin, K., \& Candirli, C. (2015). Maxillary dental anomalies in patients with cleft lip and palate: a cone beam computed tomography study. J. Clin. Pediatr. Dent., 39(2), 183-186. PMID: 25823490

[5] Dolnitsky, O. V., Galagan, V. O., \& Rodamina, O. V. (2009). Congenital malformations. Fundamentals of diagnosis and fetuses compared with the 10-month fetuses $(p<0,05)$. Considerable difference between the mean values of 10 month fetuses and newborns was not found $(p>0,05)$.

Very strong relation is found between the length of the hard palate and its width in the right and left $(r=0.92)$, between the length of the hard palate and hyoid $(r=0.97)$, between the length of the hyoid and the width of the hard palate in the right $(r=0.91)$ and in the left $(r=0.90)$.

\section{Conclusions}

1. The length of the palatine maxillary process during the perinatal period was found to be characterized by the two periods of accelerated development (5-7 and 8-10 months), and the period of relatively slow development (78 months). Its width was found to be characterized by the two period of accelerated development (5-7 and 9-10 months), and relatively slow development (7-8 months). The length of the horizontal lamina of the hyoid is characterized by the period of accelerated development from 8 to 10 months, and the period of relatively slow development from 7 to 8 months. Meanwhile 5-8 and 9-10 months were the periods of accelerated development for its width, and 8-9 months - the period of relatively slow development for it.

2. During fetal and early neonatal periods of human ontogenesis the value of all the paired correlation coefficients between organometric parameters of the palatine maxillary process (hard palate) and horizontal lamina of the hyoid are positive and rather close to 1 $(>0.84)$, which is indicative of a close positive correlation between all the organometric parameters.

3. In the second and third trimester of the intrauterine development very strong connection is found between the length of the hard palate and its width in the right and left $(r=0.92)$, between the length of the hard palate and palatine bone $(r=0.97)$, between the length of the palatine bone and the width of the hard palate in the right $(r=0.91)$ and in the left $(r=0.90)$.

treatment: monograph. Kyiv: Multi Print.

[6] Esenlik, E., Sener, E. H., Yilmaz, H. H., \& Malas, M. A. (2014). Cephalometric investigation of craniomaxillofacial structures during the prenatal period: a cadaver study. Am. J. Orthod. Dentofacial Orthop., 145(2), 217-227. doi: 10.1016/ j.ajodo.2013.09.014

[7] Faure, J. M., Captier, G., Baumler, M., \& Boulot, P. (2007). Sonographic assessment of normal fetal palate using threedimensional imaging: a new technique. Ultrasound in obstetrics \& gynecology, 29(2), 159-165. doi: 10.1002/uog.3870

[8] Ferros, I., Mora, M. J., Obeso, I. F., Jimenez, P., \& MartinezInsua, A. (2015). The nasomaxillary complex and the cranial base in artificial cranial deformation: relationships from a geometric morphometric study. Eur. J. Orthod., 37(8), 403411. doi: 10.1093/ejo/cju066

[9] Gaivoronsky, I. V., Gaivoronsky, A. V., Tvardovskaya, M. V., \& Bochkarev, I. A. (2004). Morphometric characteristics and correlations of the lacrimal sac fossa and nasolacrimal fossa 
in various forms of the cerebral and facial parts of the skull. Morphology, 126(6), 50-54.

[10] Guzik, N. M. (2005). Formation and developmental defects of some structures of the human oral area. Journal of morphology, 11(1), 24-26.

[11] Guzik, N. M. (2006). Features of the morphogenesis of the structures of the oral area in the early period of human ontogenesis. Clinical Anatomy and Operative Surgery, 5(2), 74.

[12] Mucedero, M., Franchi, L., Ricchiuti, M. R., \& Cozza, P. (2015). Association between mesially displaced maxillary first premolars and early displaced maxillary canines. Eur. $J$. Paediatr. Dent., 16(3), 45-50. PMID: 25793953

[13] Patil, M. S., Patil, S. B., \& Acharya, A. B. (2008). Palatine Rugae and Their Significance in Clinical Dentistry: A Review of the Literature. J. Am. Dent. Assoc., 139(11), 1471-1478. PMID: 18978384

[14] Sane, V. D., Gadre, K. S., Halli, R., Singh, V., Doshi, P., Saddiwal, R., \& Thopte, S. (2014). Role of cone-beam computed tomography in diagnosis and management of nasopalatine duct cyst. J. Craniofac. Surg., 25(1), 92-94. doi: 10.1097/ SCS.0000000000000427

[15] Sepulveda, W., Wong, A. E., Martinez-Ten, P., \& PerezPedregosa, J. (2010). Retronasal triangle: a sonographic landmark for the screening of cleft palate in the first trimester. Ultrasound in Obstetrics \& Gynecology, 35(1), 7-13. doi:

\subsection{2/uog.7484}

[16] Serter, S., Gunhan, K., Can, F., \& Pabuscu, Y. (2010). Transformation of the maxillary bone in adults with nasal polyposis: a CT morphometric study. Diagn. Interv. Radiol., 16(6), 122-124. doi: 10.4261/1305-3825

[17] Shi, X., Xie, X., Quan, J., Wang, X., Sun, X., Zhang, C., \& Zheng, S. (2015). Evaluation of root and alveolar bone development of unilateral osseous impacted immature maxillary central incisors after the closed-eruption technique. Am. J. Orthod. Dentofacial. Orthop., 148(10), 587-598. doi: 10.1016/ j.ajodo.2015.04.035

[18] Slobodyan, O. M., Kuznyak, N. B., Lavriv, L. P. (2016). Patterns of perinatal organometric parameters of sites and head structures. Journal of Medical and Biological Problems, 2, 2(129), 314-317.

[19] Tessler, A. Y., Franchi, L., McNamara, J. A., \& Baccetti, T. (2011). Morphometric analysis of craniofacial features in monoand dizygotic twins discordant for unilateral cleft lip and palate. Angle Orthod., 81(5), 878-883. https://doi.org/10.2319/ 121710-725.1

[20] Zaker Shahrak, A, Zor, F., Kanatas, A., Acikel, C., Sapountzis, S., Nicoli, F., ... Sonmez, T. T. (2014). Morphological and morphometric evaluation of the ilium, fibula, and scapula bones for oral and maxillofacial reconstruction. Microsurgery, 34(11), 638-645. doi: 10.1002/micr.22307

\section{ОСОБЛИВОСТІ ОРГАНОМЕТРИЧНИХ ПАРАМЕТРІВ ТВЕРДОГО ПІДНЕБІННЯ У ДРУГОМУ І ТРЕТЬОМУ ТРИМЕСТРАХ ВНУТРІШНЬОУТРОБНОГО РОЗВИТКУ ТА У НОВОНАРОДЖЕНИХ \\ Проданчук А. І., Слободян О. М., Корчинська Н. С.}

Встановлення анатомічної мінливості органів, структур та їх частин на всіх етапах розвитку людини є вельми актуальним. Встановлення органометричних параметрів твердого піднебіння у плодів та новонароджених є необхідною складовою під час проведення перинатальної діагностики та розуміння фрактичних даних норми і патології. Мета дослідження - встановити органометричні параметри піднебінного відростка верхньої щелепи і горизонтальної пластинки піднебінної кістки впродовж плодового і раннього неонатального періодів онтогенезу людини. За допомогою адекватних анатомічних методів дослідження виконано на 53 препаратах трупів плодів від 4-х до 10 місяців розвитку (від 165,0 мм до 500,0 мм тім'яноп'яткової довжини (ТПД)) та на 9-ти препаратах трупів новонароджених. Встановлено, що для довжини піднебінного відростка верхньої щелепи впродовж перинатального періоду притаманні два періоди прискореного розвитку (5-7 і 8-10 місяці) і період відносно сповільненого розвитку (7-8 місяці); для його ширини - 5-7 і 9-10 місяці є періодами прискореного розвитку, 7-8 місяці - період відносно сповільненого розвитку. Для довжини горизонтальної пластинки піднебінного кістки $\epsilon$ характерним період прискореного розвитку (8-10 місяиі) і період відносного сповільненого розвитку (7-8 місяці); для їі ширини 5-8 і 9-10 місяці - періоди прискореного розвитку, 8-9 місяці - відносно сповільненого розвитку. Упродовж плодового і раннього неонатального періодів онтогенезу значення усіх парних коефіцієнтів кореляції між органометричними параметрами піднебінного відростка верхньої щелепи (тверде піднебіння) і горизонтальної пластинки піднебінної кістки $\epsilon$ позитивними і досить близькими до 1 (>0,84), що свідчить про тісний позитивний кореляційний зв'язок між усіма органометричними параметрами. Спостерігається зв'язок дуже високої сили між довжиною твердого піднебіння та його шириною справа та зліва (r=0,92), між довжинами твердого піднебіння і піднебінної кістки (r=0,97), між довжиною піднебінної кістки і шириною твердого піднебіння справа $(r=0,91)$ та зліва $(r=0,90)$. Зв'язок дуже високої сили між довжиною твердого піднебіння та його шириною справа та зліва ( $r=0,92)$, між довжинами твердого піднебіння $і$ піднебінної кістки ( $r=0,97)$, між довжиною піднебінної кістки і шириною твердого піднебіння справа $(r=0,91)$ та зліва $(r=0,90)$. Таким чином, за допомогою адекватних анатомічних методів дослідження одержані нові науково обгрунтовані дані щодо органометричної характеристики анатомічних структур твердого піднебіння на всіх етапах перинатального періоду.

Ключові слова: піднебінний відросток верхньої щелепи, горизонтальна пластинка піднебінної кістки, морфометрія, плодовий та ранній неонатальний періоди онтогенезу людини.

\section{ОСОБЕННОСТИ ОРГАНОМЕТРИЧЕСКИХ ПАРАМЕТРОВ ТВЕРДОГО НЕБА ВО ВТОРОМ И ТРЕТЬЕМ ТРИМЕСТРАХ ВНУТРИУТРОБНОГО РАЗВИТИЯ И У НОВОРОЖДЕННЫХ Проданчук А. И., Слободян А. Н., Корчинская Н. С.}

Установление анатомической изменчивости органов, структур и их частей на всех этапах развития человека является весьма актуальным. Установление органометрических параметров твердого неба у плодов и новорожденных является необходимой составляющей при проведении перинатальной диагностики и понимания фактических данных нормы и патологии. Цель исследования - установить органометрические параметры небного отростка верхней челюсти и горизонтальной пластинки небной кости в течение плодового и раннего неонатального периодов онтогенеза человека. С 
помощью адекватных анатомических методов исследования выполнены на 53 препаратах трупов плодов от 4-х до 10 месяцев развития (от 165,0 мм до 500,0 мм теменно-пяточной длины (ТПД)) и на 9-ти препаратах трупов новорожденных. Установлено, что для длины небного отростка верхней челюсти в течение перинатального периода присущи два периода ускоренного развития (5-7 и 8-10 месяцы) и период относительно замедленного развития (7-8 месяца); для его ширины 57 и 9-10 месяцы являются периодами ускоренного развития, 7-8 месяцы - период относительно замедленного развития. Для длины горизонтальной пластинки небной кости характерно период ускоренного развития (8-10 месяцы) и период относительного замедленного развития (7-8 месяцы); для ее ширины 5-8 и 9-10 месяцы - периоды ускоренного развития, 89 месяцы - относительно замедленного развития. В течение плодового и раннего неонатального периодов онтогенеза значение всех парных коэффрициентов корреляции между органометрическими параметрами небного отростка верхней челюсти (твердое небо) и горизонтальной пластинки небной кости являются положительными и достаточно близкими к 1 (>0,84), что свидетельствует о тесной положительной корреляционной связи между всеми органометрическими параметрами. Наблюдается связь очень высокой силы между длиной твердого неба и его шириной справа и слева ( $r=0,92)$, между длинами твердого неба и небной кости ( $r=0,97)$, между длиной небной кости и шириной твердого неба справа $(r=0,91)$ и слева $(r=0,90)$. Связь очень высокой силы между длиной твердого неба и его шириной справа и слева $(r=0,92)$, между длинами твердого неба и небной кости $(r=0,97)$, между длиной небной кости и шириной твердого неба справа $(r=0,91)$ и слева $(r=0,90)$. Таким образом, с помощью адекватных анатомических методов исследования получены новые научно обоснованные данные по органометрической характеристике анатомических структур твердого неба на всех этапах перинатального периода.

Ключевые слова: небный отросток верхней челюсти, горизонтальная пластинка небной кости, морфометрия, плодовый и ранний неонатальный периоды онтогенеза человека. 